\title{
Wood species analysis of timbers from Ship A, Pisa San Rossore
}

\section{Cristina Laurenti}

MA Classical Archaeology, University of Pisa, Italy, email: crilaurenti@gmail.com

\begin{abstract}
Found in 1998 at the Pisa San Rossore site, Ship A was a medium-tonnage cargo vessel that sank in a river near the ancient city of Pisa (150-190 AD). This paper aims to present the paleo-environment formation process pertaining to theories of how the site and the associated 11 shipwrecks were sunk, followed by an analysis of Ship A. This analysis will focus on the micromorphological results of wood identification of the wreck and its conservation status. The last section of this article will discuss the result of this analysis, as an attempt to providing insights pertaining to the methodology employed for the restoration of wood and some interpretation deriving about the nature, character, and construction of Ship A.
\end{abstract}

Key words

Maritime archaeology, shipbuilding, Pisa San Rossore, wood analyses, timbers, restoration.

\section{Introduction}

In close proximity to the world-famous Leaning Tower of Pisa, more than 20 years ago archaeologists found a buried treasure of boats, ships, and archaeological objects. In 1998, during the 
course of construction works for a new logistic centre near the second railway station of Pisa, known as Pisa San Rossore Station, pieces of woods came to light (Camilli and Setari, 2005: 12-13). They were the first evidence of what emerged later to be a 'ship graveyard', which was the subject of excavations for nearly two decades. From 1998 to 2015, University-led projects, private companies, and different archaeological teams contributed to the scientific excavation of 11 shipwrecks, with them being latterly displayed at the Museum of the Ancient Ships of Pisa, that was erected exclusively to house the results of this project.

The Museum of the Ancient Ships of Pisa opened its door on 16 June, 2019 and it currently presents the results of this 17-year project in eight thematic sections, describing the history of the ancient city of Pisa (known in Roman period as the colony Opsequens Iulia Pisana), and its paleo-environment. This thematic units seek to address how the site and the 11 shipwrecks were sunk due to paleoinundation processes; followed by the evaluation of information specific to the discovery of the shipwrecks and the associated artefacts. This information is all presented in the broader narrative of ancient navigation, shipbuilding, and trade during the Roman times.

\section{Paleo-environmental process and floods events}

The city of Pisa is located on the lower alluvial plain of the Arno river, in northern Tuscany (Fig. 1). Pisa was founded at the confluence of two rivers, the Arno and the Auser, modern Serchio (which has changed its course to the north in modern times), where, in the Roman period, the environment was characterized by open spaces and intense woodland, and the site was about $4 \mathrm{~km}$ far from the sea (the distance between the coastline and the city has expanded to $9 \mathrm{~km}$ in modern times). The plain was crossed by the two rivers and their many branches. In addition, just outside the city, canals were used in Roman centuriation, which divided up the surrounding agricultural territory. The Pisa San Rossore site is located at the intersection between one of the old branches of the Auser and one of the centurial canals. The branch of the Auser must still have been connected to the sea in Roman times, in order to allow ships to transport their cargo to the city of Pisa; harbour structures have not been found but it is supposed that the city had a river port somewhere (Camilli and Setari, 2005: 19-20).

At the Pisa San Rossore site, the presence of the two rivers slowed down the current and created a deposit, a river bend, where objects carried by the flow settled. 
In addition to the presence of the fluvial current, exceptional and catastrophic floods of the Arno river, due to periods of intense rainfall, broke the riverbanks and hit the aforementioned area, sweeping away everything they encountered, and therefore creating a 'ship graveyard' (Camilli and Setari, 2005: 14-18). It is precisely because of this periodic hydrological instability that at least 11 boats sunk in the area along with their objects.

From the point of view of the depositional processes, despite the dynamic of the flood events, it is possible to understand that large quantities of water and sediments spilt into the canal river at every flood event and caused a dynamic force rapidly burying the anchored ships. The ships were buried under a thin muddy layer, that, when excavated, presented a cohesive stratified context for archaeologists, who were able to recognize alluvial phases alternated with fluvial stasis episodes. The most ancient excavated phase is dated to the Etruscan period, between the 6th and the 4th century $\mathrm{BC}$, and includes two wooden palisades, perhaps a first attempt to contain the riverbank. After this, no other traces of built structures were found - with the exception of a ballast pile or a pier connected to the centurial canal. Between the 2nd century BC and the 7th century AD several flooding events that moved from south to north, were identified (Fig. 2). The movement north of the river allowed the stratigraphic context to be buried, until its rediscovery in 1998.

The good preservation of wood has been attributed to the waterlogged deposits created by the disposition of fluvial and alluvial sediments and the lack of oxygen in the thick layers of silt and clay deposits (Camilli et al., 2005: 74-76). Evidence of good preservation is provided by the abundance and variety of organic objects discovered, such as leather scraps, ropes, wicker baskets, leaves, flowers, seeds, and in some cases, food remains in amphorae and ceramic containers. This has also contributed to the preservation of various hulls, 11 in particular, that reflect the remains of different river boats, little ferries, and cargo ships of different sizes (Bruni, 2000: 21-51).

Of these ships, Ship A was the subject of my master's thesis, addressing: the dating of the vessel, the naval architecture, the properties and condition of the timbers, as well as the configuration of the cargo, so as to hypothesize the ship's original structure.

\section{Ship A}

Ship A was the first hull identified in Pisa San Rossore and was located in trench Area 1, in the northeastern sector, bounded on the north and east sides by an iron sheet piling (Fig. 3). This sheet 
piling was put in place before the beginning of the excavation and had accidentally, but unfortunately, cut the ship into two parts (Bruni, 2000: 45). The south-west section was completely excavated whereas the north-east section still remains in situ, unexcavated, because of the train tracks on top of the wreck.

Several interventions have occurred in Area 1 over the past 20 years. During season one, 1998-1999, the Co.Idra company scientifically excavated a small portion of the hull that was the first brought to light during the construction works. However, given the expertise necessary for such a job, Co.Idra chose not to continue the excavation after other hulls were starting to appear in the area.

Season two took place in 2003 and involved archaeology students from Pisa University. This project was coordinated by Dr Angelina De Laurenzi, and in this season students re-excavated the context initially exposed by Co.Idra, and subsequently enlarged, exposing an additional portion of the hull. Area 1 was not excavated further, and the hull of Ship A were covered with sand and geotextile (Leoncini, 2007: 6).

Season three took place three years later, between 2006 and 2007, by SeArch company. In these two years, SeArch undertook the stratigraphically excavation of the entire area, exposing the complete hull of Ship A. With the completion of the project the hull was covered with sand and geotextile. In 2013-2014, Cooperativa Archeologia, was responsible for dismantling the hull and sent the remains to a storage unit, so as to be reconstructed, and latterly displayed in the new museum of Pisa (Mileti, 2011: 43-44; Remotti, 2012: 14-18).

These excavation projects concluded that Ship A has was a medium-tonnage cargo, of shell-fist construction, 20-30 m long, perhaps used for offshore navigation. The construction sequence of Ship A was based around the keel that was put in place first, followed by floor-timbers, then planks. Later on, the other framing timbers were inserted followed by a keelson and two smaller side keelsons. Framing included half-frames, floor-timbers, and futtocks, all of which were fastened to the planking with mortise-and-tenon joints. Preliminary dating results deriving from the vessel's construction method and the related materials, and artefacts found in the associated stratigraphy, seem to be consistent with the results of the radiometric analysis of the wreck timbers, which suggest that Ship 
A sunk approximately between AD 150 and 190. Further information about the structure and construction of Ship's A will be published in association with the catalogue of the Museum of the Ancient Ships of Pisa.

\section{Wood species analyses and discussion}

In order to understand the condition of the timbers, the level of damage, and the wood species, two micromorphological analyses were carried out. The first in 2006 dealt only with a small part of the planking, some frames, the keelson, and three timbers of the ceiling. While the second analysis, in 2014, was concerned with a larger part of the hull and aimed to identify the various timbers-types. Both analyses were undertaken by the CNR-IVALSA laboratory (Sesto Fiorentino, Florence, Italy).

The analyses were carried out through the observation of thin sections of the wood using an optical microscope and were identified by comparison with specialist collections in texts and databases (Giachi, et al., 2009: 2-5; Pizzo et al., 2014: 3-7).

The results revealed a consistent pattern (Fig. 4), as the majority of the frames were made out of oak (Quercus sp. p.), with others made from ash (Fraxinus sp. p.), walnut (Juglans regia) and elm (Ulmus sp. p.). The planking was made of maritime pine wood (Pinus pinaster) and the keelson was made of oak. The two side keelsons were made of maritime pine as were the few ceiling planks. Only two small timbers were made from different types of wood, such as cypress (Cupressus sempervirens) and scots pine (Pinus sylvestris), which may indicate of repairs, as do the presence of a few frames in elm, ash, and walnut. Because of poor conservation, a few timbers remained unidentified, and in some cases, it was possible to establish if they were coniferous or deciduous wood only, but not identify the species (Giachi, et al., 2009: 5-6; Pizzo et al., 2014: 12-15).

A separate dendrochronological study, undertaken by DENDRODATA s.a.s. laboratory, examined the wood of the keel with the results suggesting that the keel timbers, found in three parts connected with scarf joints with cogs (trait de Jupiter), were made from two different types of oak. One section was made out of Quercus sp. section SUBER, an evergreen oak, the other section was in Quercus sp. section ROBUR, a deciduous oak. Unfortunately, it was not possible to specify the exact species because they are not easily distinguishable (Martinelli and Pignatelli, 2015: 15-19). 
Overall, oak was one of the most frequent woods used in naval carpentry due to its mechanical strength, its abundant availability in the surrounding area, and commonly used by carpenters for keels and frames, due to its known durability and resistance to biotic attack. Concerning the two types of oak: SUBER section contains trees such as the holly oak (Quercus ilex L.), cork oak (Quercus suber L.) and kermes oak (Quercus coccifera L.); ROBUR section includes the European oak (Quercus Robur L.), sessile oak (Quercus petraea), and downy oak (Quercus pubescens Willd.). These types of oak pertain to a mixture of local and import species widely documented in Roman naval carpentry for their technological characteristics.

Ash and elm were known for their mechanical features, even if sometimes they were not so easy to work due to the presence of interlocking fibres, and their elasticity, which made them suitable for frames (Giachi et al., 2017: 182-183). With regard to walnut, it was only occasionally used in ancient shipbuilding as it was prone to insect attack (Antico Gallina, 2011: 258). The presence of walnut is surprising and perhaps pertains to evidence of rapid repairs, which could have been made locally at the site of Pisa San Rossore, since walnut trees were (and still are) locally available. Therefore, this could suggest perhaps that carpenters were present at the abovementioned site.

Pine was the most commonly used wood because of its availability, flexibility, strength, and resistance to degradation. Maritime pines and scots pines were also two of the most accessible trees in the Mediterranean area. In addition, by-products, such as pitch for caulking, were also evident in the interior of the hull.

Mediterranean cypress, a widely cultivated plant since antiquity, was also appreciated for its high durability, even if it was only found in a limited part of the planking of Ship A (Giachi et al., 2017: 182).

The use of different woods postulates that Ship A was assembled using the most available materials that the carpenters could easily find nearby. The presence of walnut, which is somewhat unusual, can perhaps be understood when viewed in a broader context when compared with the other ships found in the same context. For example, Ship D - a large river boat dated at the end of the 5th century AD - shows parts of the planking made out of walnut, and the same for Ships F and H. These two small river boats, initially dated to the middle Imperial period, were most likely built locally using trees 
harvested from the immediate vicinity of the site. It is therefore possible to hypothesize that Ship A was repaired near Pisa San Rossore, with this particular type of wood being preferred by local carpenters (Giachi et al., 2017: 178-181).

The timber analysis has not been successful in ascribing an area of origin for Ship A. In this instance, however, the analysis has shown that the wood used for the construction of Ship A were typical of ancient shipbuilding traditions seen throughout the coasts of the Mediterranean Sea. Different types of oak as well as ash, walnut, elm, scots pine, and cypress are easily available in the Tuscan region especially in Roman times, when the climate favoured these types of trees (Giachi et al., 2017: 178183). Concerning maritime pine, the use of this species undoubtedly recalls the Pisan area considering that maritime pine tree is the most common tree found around and inside the city still today. Similar patterns of wood use were observed in the other Pisa ships, both river boats and cargo vessels, (Bruni, 2000: 80-86; Giachi et al., 2017: 178-182), as well as in the three Roman ships found in Naples in 2004 (Capretti et al., 2008: 871-874). This, therefore suggests that during the Roman period there were ships preferred wood species, at least for the fundamental structural parts of the vessel, such as the keel and frames, whereas other, secondary parts of the vessel, such as planking, would have been built with locally available timbers. For instance, Theophrastus in his Historia Plantarum and Pliny the Elder in Naturalis Historia, provide information about shipbuilding and timber, that seem compatible with to Ship A construction and wood choice. Both sources praise the properties of pine trees, which they also recognize as the most employed wood type in ancient naval carpentry (Theophrastus: V, 7, 3), while Strabo, the Greek geographer, and Pliny the Elder stated that in ancient times Pisa was world-famous for its wood, traded especially for the purpose of naval construction (Strabo: V, 2, 5; Pliny: XIII, 3-39 and XVIII, 86-87). In light of this information, it is therefore possible to postulate that Ship A rather than presenting unique insights into Mediterranean shipbuilding, rather reinforces what is currently known about the wood choice.

\section{Conservation status and restoration}

Ship A timbers, in their state of maximum imbibition, presented evidence of degradation over time. As a matter of fact, the wood appears to have a spongy consistency and the timbers were broken at different places.

The results of the micromorphological analyses undertaken in 2006 and 2014, which involved a chemical and physical characterization, together with an inorganic component characterization, 
suggested that there was a widespread attack by xylophagous organisms, mainly erosion type bacteria and soft-rot fungi. The relevance of the damage suffered by the timbers is underlined by the fact that the residual polysaccharide component was below the $10 \%$, with the exception of the pine wood, confirming that coniferous woods are more resistant to degradation in conditions of imbibition and substantial anoxia than deciduous trees. In addition, the high level of wood degradation is confirmed by the presence of a high content of inorganic matter (around 10\% of the total weight), primarily made up of iron and calcium oxides (Giachi, et al., 2009: 7-10; Pizzo et al., 2014: 16-30).

Based on this alarming information, conservators decided that it was necessary to undertake an appropriate restoration. The cargo timbers were restored using Kauramin, a BASF licence, that is a resin made from melamine and soluble formaldehyde. The procedure included the wood being immersed in the Kauramin solution, followed by the timbers been washed and dried in an oven at $50^{\circ} \mathrm{C}$. As a part of the restoration process, epoxy resin was added to re-establish the original colour and texture of the wood (Barreca, 2015: 2-3). The outcome of this process saw the display and reassembling of Ship A in section four at the Museum of the Ancient Ships of Pisa (Fig. 5).

\section{Conclusion}

To conclude, the site of Pisa San Rossore, was created as a result of river-line intersections and different paleo-climatic events, the consequence of which was the submergence of 11 Roman ships. Archaeological data suggest these events first started, during the 6th century BC and occurred more frequently during the Roman period. Ship A, studied here, was one of the Roman ships, submerged during the course of one of these paleo-climatic events. The analysis of the wood species suggests that the vessel was made out of typical materials used in the ancient shipbuilding, traditionally found throughout the Mediterranean Sea. The keel, keelson, most of the frames, and a part of the planking were made of oak, whereas other elements of the framing were made from elm, ash, and walnut. The two side keelsons, along with the ceiling and the planking were made out of maritime pine, with the exception of one small timber made from cypress. The presence of these types of wood suggests that the area of origin of the timbers, and consequentially of the ship, may be the Tyrrhenian hinterland, perhaps the region of Pisa. Furthermore, the use of these species is reflected in the works of the ancient authors, mainly Theophrastus and Pliny the Elder, when describing shipbuilding. All these data improve knowledge of middle Imperial-age shipbuilding, and provide insights into ancient naval architecture, pertaining to the craftsmanship of carpenters and ship technology in the Roman period. 


\section{Acknowledgements}

For this publication, I would like to thank the MAGS 2020 committee. I am also grateful to the Honor Frost Foundation for allowing me to publish my work. Finally, and most importantly, I would like to sincerely thank Mr Andrea Camilli, who provided me with the material to study.

\section{Reference List}

Antico Gallina, M., 2011, Archeologia del legno. Uso, tecnologia, continuità in una ricerca pluridisciplinare. Milan: EDUCatt.

Barreca, D., 2015, Trattamento Sperimentale d'impregnazione con Kauramina su campioni di legno provenienti dal sito di Pisa San Rossore (Nave A, Nave I). Florence: Cooperativa Archeologia.

Beltrame, C., 2012, Archeologia marittima del Mediterraneo: navi, merci e porti dall'antichità all'età Moderna. Rome: Carrocci Editore.

Bonino, M., 2005, Argomenti di architettura navale antica. Pisa: Felici.

Bruni, S., 2000, Le Navi Antiche di Pisa: ad un anno dall'inizio delle ricerche. The Ancient Ships of Pisa: after a year of work. Florence: Polistampa.

Camilli, A. et al., 2005, Stratigrafia fluviale, portuale e terrestre. La sequenza dello scavo delle Navi di Pisa - S. Rossore, in B. M. Giannattasio (ed.) Aequora, portos, jam, mare. Mare, uomini e merci nel Mediterraneo antico, Proceedings of the International Symposium, Genoa, 2004, 74-86.

Camilli, A. and Setari, E., 2005, Le Navi Antiche di Pisa. Guida archeologica. Rome: Mondadori Electa.

Capretti, C. et al., 2008, The characterization of waterlogged archaeological wood: the three Roman ships found in Naples (Italy). Archaeometry 50 (5), 855-876.

Giachi, G. et al., 2009, Un nuovo passo nella diagnostica del legno dei relitti di Pisa: La Nave A, in Biscontin G. (ed), Conservare e restaurare il legno. Conoscenze, esperienze, prospettive, Proceedings of the XXV Convegno di Studi, Bressanone (Bolzano), 2009, 1-10.

Giachi, G. et al., 2017, Identification of wood from Roman ships found in the docking site of Pisa (Italy). Journal of Cultural Heritage 23, 176-184. 
Leoncini, E., 2007, Pisa San Rossore. Materiali ceramici dal carico della Nave A (US 1010). Gradus. Rivista di archeologia subacquea 2.1, 6-15.

Martinelli, N. and Pignatelli, O., 2015, Datazione assoluta dei relitti rinvenuti nello scavo di Pisa San Rossore. Nuove indagini sul relitto A. Relazione tecnico-scientifica. Verona: DENDRODATA s.a.s.

Mileti, M.C., 2011, Cantiere Di Pisa - San Rossore: Area 1 - Nave A. Ricostruzione delle modalità di naufragio e successivo interro del relitto attraverso le analisi delle stratigrafie e lo studio dei materiali archeologici (Unpublished PhD dissertation, Pisa University), Pisa.

Plinius, Gaius Secundus, Naturalis Historia.

Pizzo, B. et al., 2014, Relazione valutazione dello stato di conservazione della nave A e della nave I. Sesto Fiorentino: CNR-IVALSA.

Remotti, E., 2012, Il bagaglio di un marinaio. Rome: Aracne Editrice.

Strabo, Geographica.

Theophrastus, Historia Plantarum. 
Figures

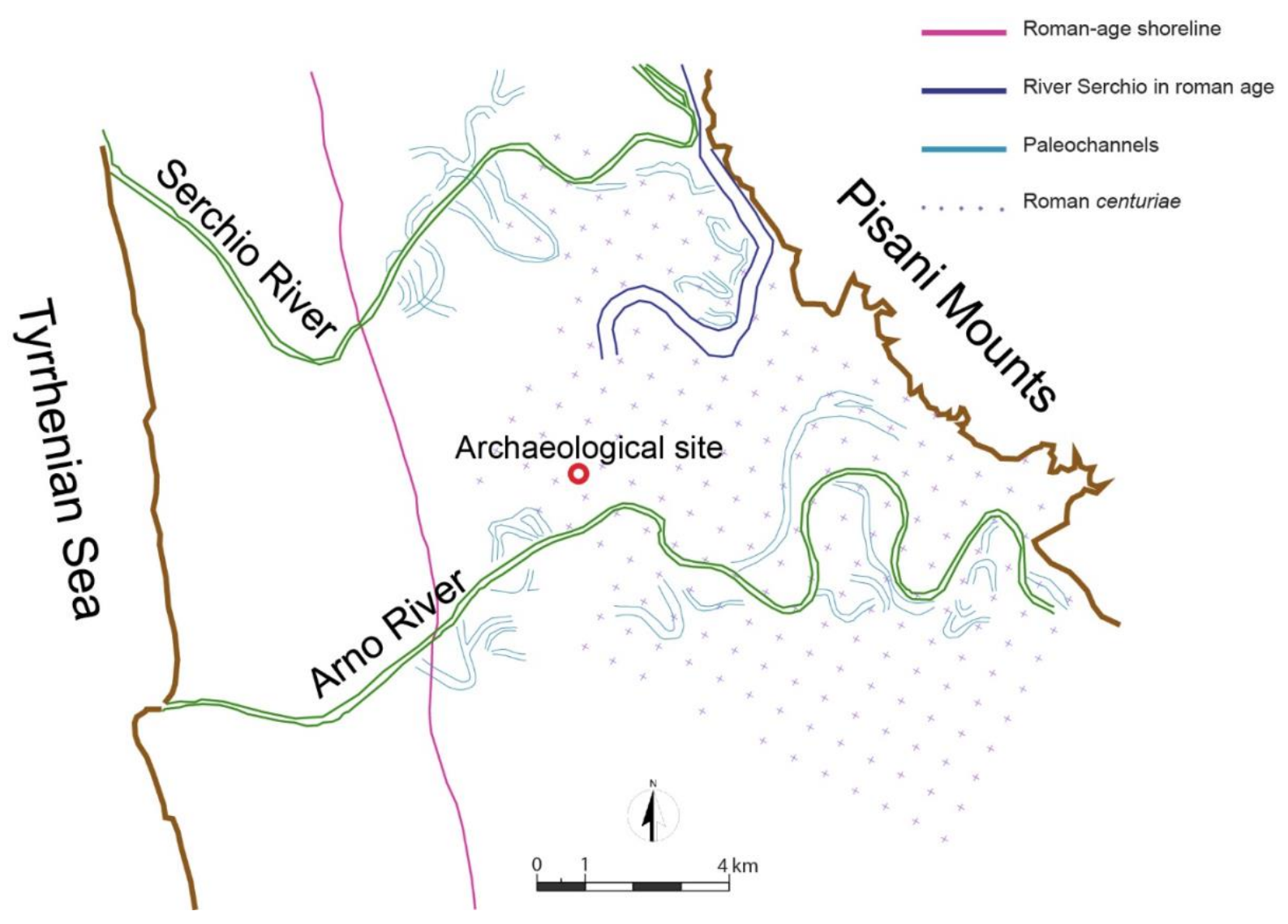

Fig. 1: Schematic map of Pisa San Rossore area with modern rivers and paleochannels (Author's rendition of a satellite image). 


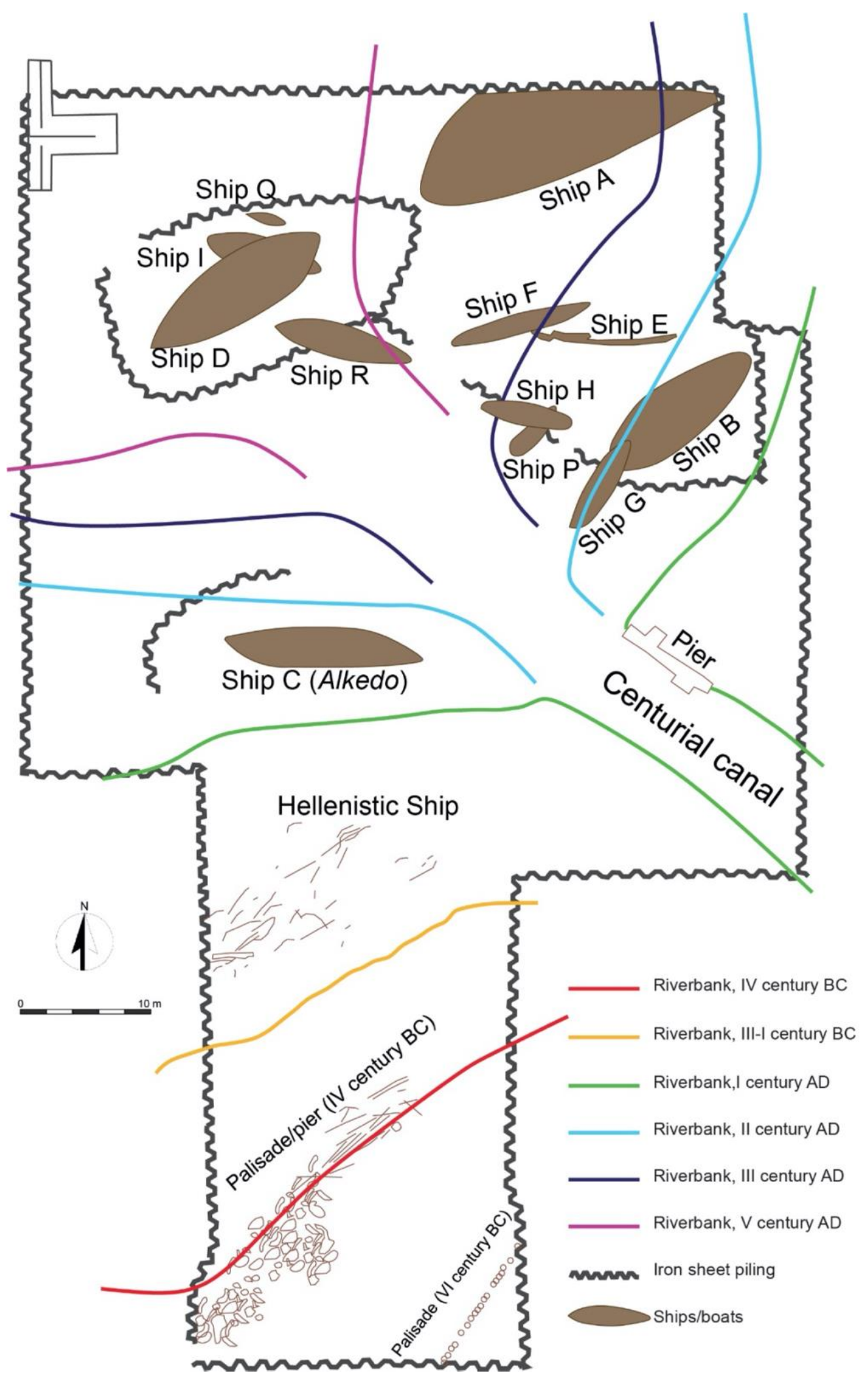

Fig. 2: Excavation map with shipwrecks and chronological phases (Author, based on excavation map, Soprintendenza Archeologia, Belle Arti e Paesaggio per le province di Pisa e Livorno). 


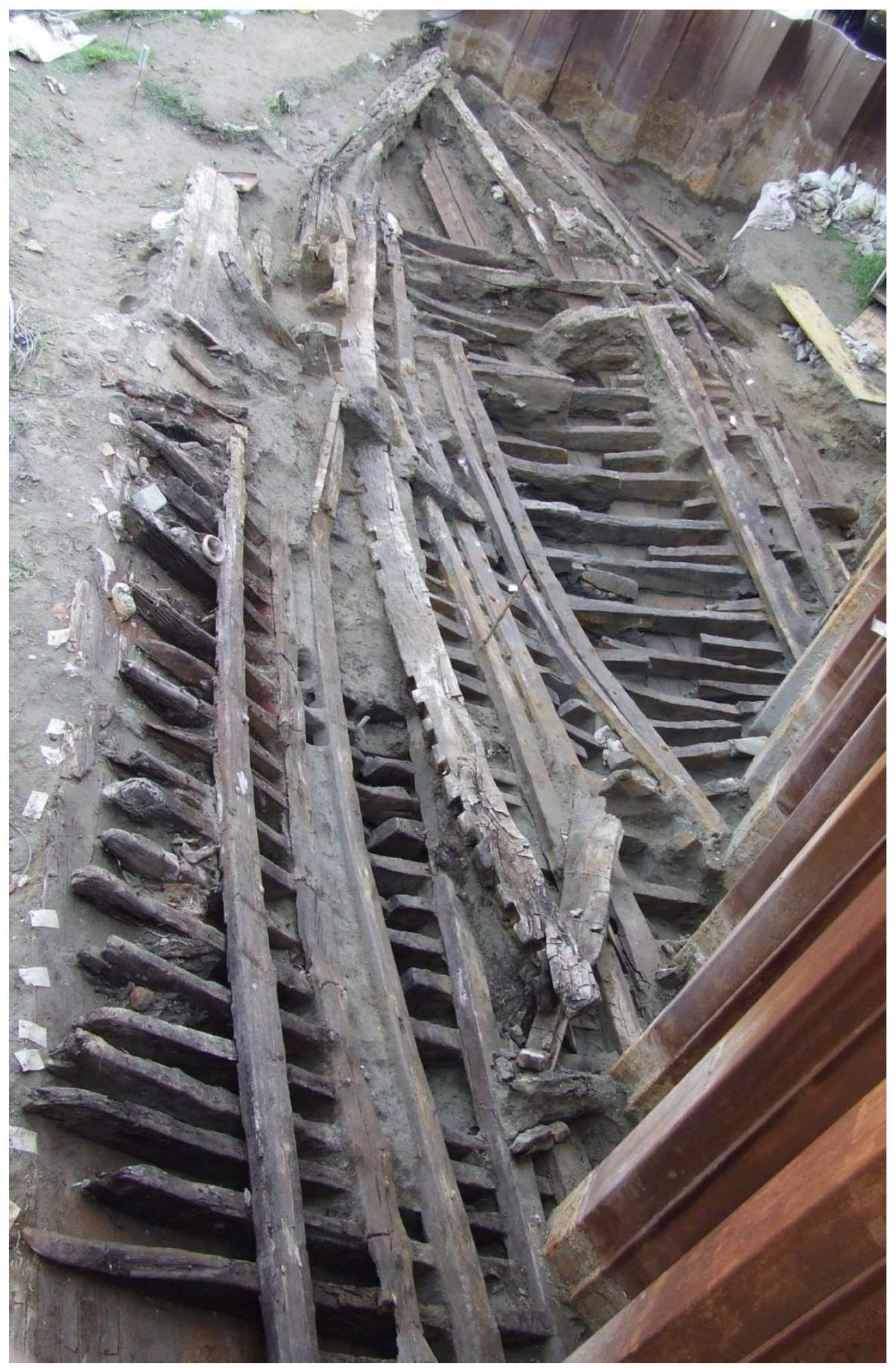

Fig. 3: Ship A during the 2006-2007 excavation (Archive image, Soprintendenza Archeologia, Belle Arti e Paesaggio per le province di Pisa e Livorno). 


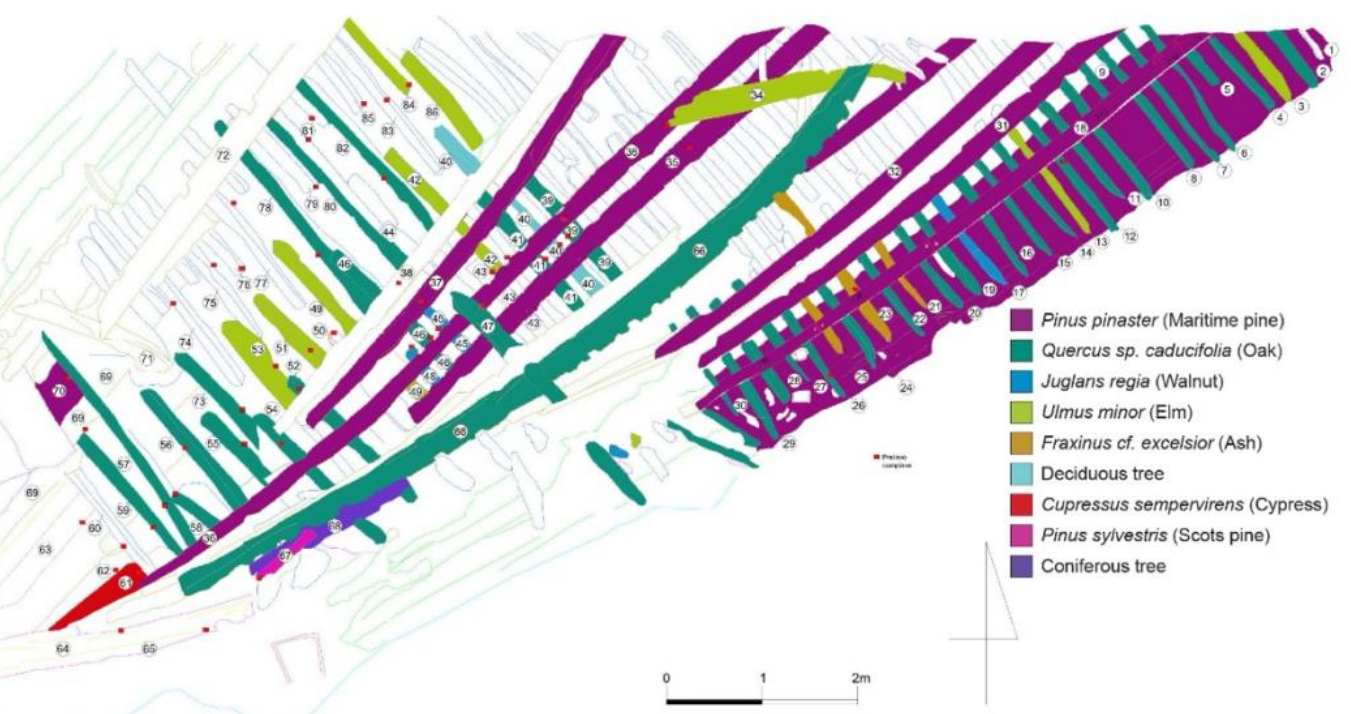

Fig. 4: Map of the different wood species (Author, based on excavation map, Soprintendenza Archeologia, Belle Arti e Paesaggio per le province di Pisa e Livorno).

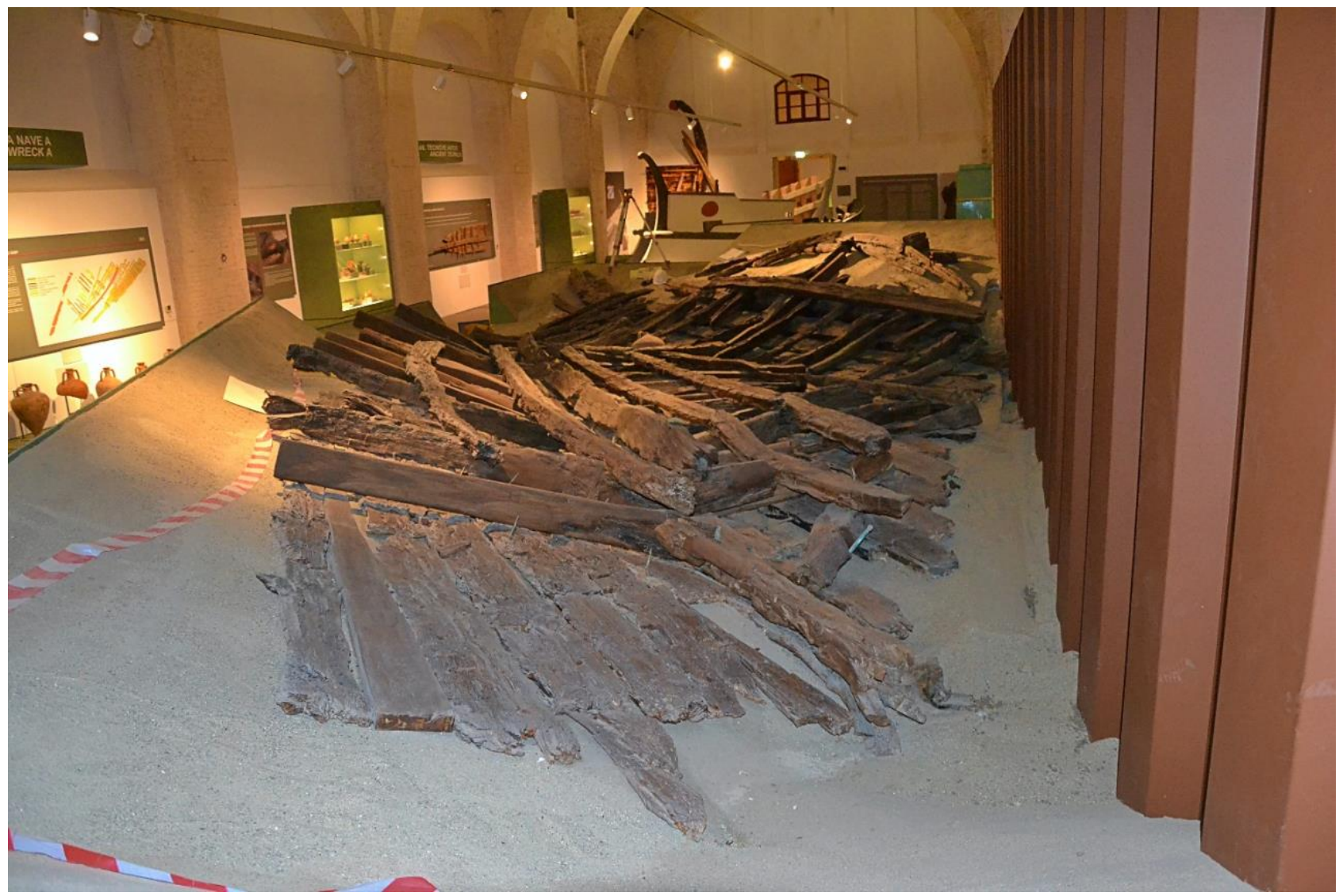

Fig. 5: Ship A remains in section 4 of the Museum of the Ancient Ships of Pisa (Photo: author). 